\title{
Analisis Pengaruh Syari'ah Compliance dan \\ Islamic Corporate Governance terhadap Tindakan Fraud (Studi Empirik pada BUS di Indonesia Periode 2013-2017)
}

\author{
Rifqi Muhammad \\ Program Studi Akuntansi Universitas Islam Indonesia \\ Email: rifqimuhammad@uii.ac.id \\ Ratna Kusumadewi \\ Sekolah Pascasarjana Universitas Gajdah Mada \\ Email: ratnakusumadewi024@gmail.com \\ Samsubar Saleh \\ Program Studi Ilmu Ekonomi Universitas Gajah Mada \\ Email: ssamsubar@yahoo.com
}

\begin{abstract}
Abstrak:
This study aims to provide empirical evidences whether the Profit Sharing Ratio (PSR), Islamic Investment Ratio (IIR), Islamic Income Ratio (IsIR), Zakat Performance Ratio (ZPR), and Islamic Corporate Governance (ICG) affect the Fraud Actions on Full-fledge Islamic banks in Indonesia. This study is a quantitative study using panel data in the period of 2013 to 2017 with a sample of 12 Islamic banks in Indonesia. The study employs Data Panel Regression with E-views 7.0 software. The results of the study indicate that the Profit Sharing Ratio (PSR), and Islamic Investment Ratio (IIR) have a significant influence on fraudulent actions. While the independent variable Islamic Income Ratio (IsIR), Zakat Performance Ratio (ZPR), and Islamic Corporate Governance (ICG) do not have a significant effect on fraudulent actions.

[Tujuan penelitian ini untuk memberikan bukti empirik apakah Profit Sharing Ratio (PSR), Islamic Invesment Ratio (IIR), Islamic Income Ratio (IsIR), Zakat Peformance Ratio (ZPR), dan Islamic Corporate Governance (ICG) berpengaruh terhadap Tindakan Fraud Pada Bank Umum Syariah di Indonesia. Penelitian ini merupakan penelitian kuantitatif dengan menggunakan data panel untuk periode 2013 sampai dengan 2017 dengan sampel 12 Bank Syariah di Indonesia. Penelitian ini menggunakan metode analisis Regresi Data Panel dengan software E-views 7.0. Hasil penelitian menunjukkan bahwa Profit Sharing Ratio (PSR), dan Islamic Invesment Ratio (IIR) memiliki pengaruh yang signifikan terhadap tindakan Fraud. Sedangkan variabel independen Islamic Income Ratio (IsIR), Zakat Peformance Ratio (ZPR), dan Islamic Corporate Governance (ICG) tidak memiliki pengaruh yang signifikan terhadap tindakan Fraud.]
\end{abstract}

Kata Kunci: Syari'ah Compliance; Islamic Corporate Governance; Fraud. 


\section{PENDAHULUAN}

Saat ini di Indonesia diperkenalkan sistem perbankan yang berbasis syariah yang dapat menjadi bank alternatif bagi masyarakat Indonesia khususnya umat muslim di Indonesia. Setelah itu muncul pemberlakuan undang-undang no 21 tahun 2008 tentang Perbankan Syariah yang memberikan landasan hukum yang kuat bagi perbankan syariah dan memberikan kesempatan yang lebih luas bagi perbankan syariah dalam mengembangkan jaringan perbankan syariah terutama membuka jaringan kantor cabang syariah oleh bank konvensional, dengan demikian bank syariah semakin berkembang. Semakin berkembangnya bank syariah membuat tantangan yang dihadapi bank syariah semakin besar, terutama dalam mempertahankan reputasi yang baik agar para nasabah akan tetap percaya dan loyal terhadap bank syariah. ${ }^{1}$ Dalam menjalankan kegiatan usahanya, bank syariah selalu menerapkan nilai-nilai Islam dalam lingkungan perusahaan, yang berpedoman dari al-Qur'an, Hadis dan Ijma' para ulama. ${ }^{2}$

Sejak satu dekade terakhir kasus fraud meningkat secara substansial terutama kasus fraud di lembaga keuangan. Di Indonesia, kasus fraud pernah menimpa lembaga keuangan syariah yaitu Bank Mandiri Syariah. Kasus ini melibatkan pihak internal bank, yaitu berupa penyaluran pembiayaan fiktif pada Bank Syariah Mandiri kantor cabang Bogor sebesar 102 miliar rupiah kepada 197 nasabah fiktif. Akibat dari penyaluran pembiayaan tersebut Bank Syariah Mandiri mengalami kerugian sebesar 59 miliar rupiah. ${ }^{3}$ Kasus fraud juga pernah menimpa negara lain seperti yang dialami Dubai Islamic Bank yang harus kehilangan dana sebesar US\$ 300 miliar yang disebabkan karena financial statements yang buruk. Selain itu Islamic Bank of South Africa juga mengalami kasus fraud akibat dari manajemen dan sistem akuntansi yang buruk dan tidak tepat, sehingga bank tersebut mengalami kebangkrutan yang disebabkan hutang yang berkisar R50 hingga R70 juta. ${ }^{4}$ Dengan munculnya kasus-kasus fraud yang terjadi di lembaga syariah, sangatlah dibutuhkan pedoman untuk mencegah dan meminimalisir potensi terjadinya tindakan fraud tersebut.

Hameed et al. dalam Asrori, menyarankan Islamic Disclosure Index (IDI) yang terdiri dari tiga indikator berupa sharia compliance, corporate governance, dan social/environment disclosure. 5 Untuk mengukur kepatuhan syariah dapat menggunakan pengukuran Islam yang telah dikembangkan menjadi beberapa pengukuran, antara lain: profit sharing ratio, zakat performance ratio, equitable distribution ratio, directors - employees welfare ratio, islamic investment vs non investment ratio, islamic income vs non income ratio, dan AAOIFI index.

Penelitian ini mengacu penelitian dari Najid dan Rini, yang menggunakan 3 proksi dari pengukuran kepatuhan syariah di atas yaitu: Profit Sharing Ratio (PSR), Islamic Investment Ratio (IIR), dan Islamic Income Ratio (IsIR). 6 Perbedaan penelitian ini dengan penelitian yang dilakukan oleh Najib dan Rini, dalam penelitian kali ini, peneliti menggunakan 4 proksi dari pengukuran kepatuhan syariah diatas yaitu : Profit Sharing Ratio (PSR), Islamic Investment Ratio (IIR), Islamic Income Ratio (IsIR), Zakat Performance Ratio

\footnotetext{
1 Falikhatun and Yasmin Umar Assegaf, "Bank Syariah Di Indonesia : Ketaatan Pada Prinsip-Prinsip Syariah Dan Kesehatan Finansial," Conferene in Business, Accounting and Management-FE UNISSULA 1 No. 1, no. Desember (2012): 245-54.

2 Aldira Maradita, "Karakteristik Good Corporate Governance," Yuridika 29, no. 2 (2014): 191-204.

3 "Setitik Nila Di Perbankan Syariah," Stabilitas, 2013, http://stabilitas.co.id/home/detail/setitik-nila-diperbankan-syariah.

${ }^{4}$ Rini, "The Effect of Audit Committee Role and Sharia Supervisory Board Role on Financial Reporting Quality at Islamic Banks in Indonesia," Journal of Economics, Business, and Accountancy/ Ventura 17, no. 1 (2014): 145-56.

${ }^{5}$ Asrori, "Pengungkapan Syari'Ah Compliance Dan Kepatuhan Bank Syariah Terhadap Prinsip Syariah," JDA Jurnal Dinamika Akuntansi 3, no. 1 (2011): 1-7.

6 Haifa Najib and Rini, "Sharia Compliance, Islamic Corporate Governance, Dan Fraud Pada Bank Syariah," Akuntansi Dan Keuangan Islam 4.2, no. i (2016): 131-46.
} 
(ZPR). Alasan peneliti menambahkan 1 (satu) proksi lainnya karena proksi zakat performance ratio memiliki peluang pengaruh lebih besar terhadap fraud di bank syariah berdasarkan teori Sharia Enterprise Theory.

Selain kepatuhan syariah, penerapan good corporate governance (GCG) terbukti bisa meningkatkan citra/reputasi serta kepercayaan masyarakat kepada bank syariah. Menurut Chapra, M.U. dan Ahmed, kegagalan bank syariah dalam melaksanakan penerapan prinsip syariah akan berdampak terhadap loyalitas nasabah, dimana nasabah akan berpaling atau pindah ke bank lain sebesar 85\%.7 Dengan demikian, penerapan syari'ah complince dan penerapan good corporate governance (GCG) menjadi sebuah keharusan dan kewajiban bagi perbankan syariah di Indonesia dalam upaya memperbaiki citra dan kepercayaan pada bank syariah.

Berdasarkan fenomena di atas, peneliti tertarik untuk meneliti apakah syari'ah compliance dan islamic corporate governance berpengaruh terhadap tindakan fraud pada bank syariah. Penelitian ini secara garis besar dilakukan untuk menjelaskan gejala-gejala yang terjadi terkait dengan variabel-variabel yang berpengaruh terhadap tindakan fraud pada perbankan syariah dilihat dari faktor kepatuhan syariah yang di proksikan ke dalam, profit sharing ratio, Islamic investment ratio, Islamic income ratio, zakat performance ratio dan Islamic corporate governance. Penelitian ini bersifat kuantitatif dengan data diperoleh dari laporan keuangan dan laporan good corporate governance yang dipublikasikan oleh setiap bank syariah. Tindakan fraud digunakan sebagai variabel independen dikarenakan masih banyaknya tindakan fraud yang terjadi di perbankan syariah. Berdasarkan latar belakang masalah yang telah diuraikan, pertanyaan penelitian dalam penelitian ini yaitu Apakah Profit Sharing Ratio (PSR), Islamic Invesment Ratio (IIR), Islamic Income Ratio (IsIR), Zakat Peformance Ratio (ZPR), dan Islamic Corporate Governance (ICG) berpengaruh terhadap fraud pada Bank Umum Syariah di Indonesia?

\section{METODOLOGI PENELITIAN}

Populasi dalam penelitian ini yaitu Bank Umum Syariah di Indonesia Periode 20132017. Teknik pengambilan sampel menggunakan purposive sampling yaitu pemilihan sampel not random yang informasinya diperoleh dengan pertimbangan atau kriteria tertentu. Kriteria tersebut yaitu Bank Umum Syariah yang terdaftar di OJK Periode 2013-2017 dan mempublikasikan laporan keuangan tahunan dan laporan pelaksanaan GCG secara lengkap periode 2013-2017. Berdasarkan kriteria tersebut maka dihasilkan 12 bank umum syariah meliputi: PT. Bank Muamalat Indonesia, PT. Bank Syariah Mandiri, PT. Bank BRI Syariah, PT. Bank BNI Syariah, PT. Bank Victoria Syariah, PT. Bank Mega Syariah, PT. Bank Jabar Banten Syariah, PT. Bank Panin Dubai Syariah, PT. Bank Syariah Bukopin, PT. BCA Syariah, dan PT. Maybank Syariah Indonesia, PT. Bank Aceh Syariah. Data dalam penelitian ini diambil secara online pada website perusahaan perbankan syariah yang terkait dengan cara di download sesuai dengan kebutuhan data.

Analisis data dalam penelitian ini menggunakan data panel. Regresi data panel merupakan teknik regresi yang menggabungkan data runtut waktu (time series) dengan data silang (cross section) ${ }^{8}$. Menurut Widarjono metode estimasi model regresi data panel dapat dilakukan melalui tiga pendekatan, antara lain: yaitu model common effect (CE), model fixed

\footnotetext{
7 Habib Caphra, M.U. \& Ahmed, “Corporate Governance In Islamic Financial Institutions.,” Occasional Paper No. 6 Jeddah 13, no. 4 (2002): 375-89.

8 Agus Tri Basuki, Analisis Regresi Dalam Penelitian Ekonomi \& Bisnis: Dilengkapi Aplikasi SPSS \& Eviews Jakarta: Rajawali Pers, 2016.
} 
effect (FE), dan model random effect (RE). ${ }^{9}$ Untuk memilih model terbaik dalam mengestimasi data panel terdapat tiga cara yaitu uji chow, uji hausman dan uji LM. Uji cow bertujuan untuk memilih antara model common effect (CE) atau model fixed effect (FE) yang paling baik untuk digunakan dalam penelitian. Uji hausman bertujuan untuk memilih model Fixed Effect atau Random Effect yang paling tepat digunakan dalam penelitian. Sedangkan Uji LM untuk mengetahui apakah model random effect lebih baik dari pada metode commont effect. Uji Asumsi klasik yang harus dipenuhi dalam regresi data panel yaitu uji multikolinieritas, uji autokorelasi dan uji heteroskedasitas. Uji hipotesis dan analisis data panel terdiri dari uji $\mathrm{F}$, uji T, dan uji koefisien determinasi.

\section{Definisi Operasional dan Pengukurannya}

Variabel dependen ( $\mathrm{Y}$ ) dalam penelitian ini adalah fraud. Variabel ini diukur dengan melihat jumlah internal fraud yang terjadi di bank syariah yang terdapat di dalam laporan tahunan pelaksanaan GCG setiap bank syariah.

Variabel independen (X) pada penelitian ini adalah syari'ah compliance dan Islamic Corporate Goverance. Syari'ah Compliance diukur dengan menggunakan 4 (empat) proksi. Proksi tersebut terdiri dari:

Profit Sharing Ratio (PSR) adalah rasio pengukuran yang mengambarkan perbandingan antara jumlah pembiayaan mudharabah dan musyarakah dengan total pembiayaan. ${ }^{10}$ Proksi PSR dalam penelitian ini dapat dilihat di dalam laporan tahunan/Annual Report Bank Syariah. Rumus dari Profit Sharing Ratio (PSR) adalah sebagai berikut:

$$
\text { PSR }=\frac{\frac{\text { Pembiayaan Mudaharabah }+ \text { Pembiayaan Musyarakah }}{\text { Total Pembiayaan }}}{\text { Teman }}
$$

Islamic Invesment Ratio (IIR) adalah rasio pengukuran yang menggambarkan perbandingan antara investasi halal dengan total investasi (halal dan non halal). ${ }^{11}$ Proksi IIR dalam penelitian ini dapat dilihat di dalam laporan tahunan/Annual Report Bank Syariah. Rumus dari Islamic Invesment Ratio (IIR) adalah sebagai berikut:

$$
\text { IIR }=\frac{\text { Investasi Halal }}{\text { Investasi Halal+Investasi Non Halal }}
$$

Islamic Income Ratio (IsIR) merupakan rasio pendapatan halal terhadap total pendapatan secara keseluruhan (halal dan non halal).12 Pendapatan non halal diungkapkan di dalam laporan sumber dan penggunaan dana kebajikan pada laporan tahunan/Annual Report. Rumus dari Islamic Income Ratio adalah sebagai berikut:

$$
\text { ISIR }=\frac{\text { Pendapatan Halal }}{\text { Pendapatan Halal+Pendapatan Non Halal }}
$$

\footnotetext{
${ }^{9}$ Agus Widarjono, Ekonometrika Pengantar Dan Aplikasinya Yogyakarta: Ekonisia FE UII, 2009.

10 Shahul Hameed et al., "Alternative Disclosure and Performance Measures for Islamic Banks," 2004, https://doi.org/10.1017/CB09781107415324.004.

11 Ibid.

12 Ibid.
} 
Zakat Peformance Ratio (ZPR) merupakan rasio yang membandingkan jumlah zakat terhadap net assets. ${ }^{13}$ Rumus dari Zakat Performace Ratio adalah sebagai berikut:

$$
\mathrm{ZPR}=\frac{\text { Zakat }}{\text { Net Asset }}
$$

Islamic Coporate Governance (ICG) dalam penelitian ini diukur dengan melihat nilai komposit hasil self assessment Good Corporate Governance (GCG) bank syariah yang diungkapkan pada laporan GCG bank Syariah.

\section{HASIL DAN PEMBAHASAN \\ Pemilihan Model Regresi Data Panel}

Tabel 1

Uji Chow-test atau likelihood-test

\begin{tabular}{cc}
\hline Effects Test & Prob. \\
\hline Cross-section $F$ & 0.0000 \\
Cross-section Chi-square & 0.0000 \\
\hline
\end{tabular}

Berdasarkan hasil uji Uji Chow-test atau likelihood-testtabel dengan menggunakan Eviews, didapatkan nilai probabilitas Chi-square sebesar 0,0000 < (alpha) 5\%. Sehingga dapat disimpulkan model terbaik yang digunakan dalam penelitian ini yaitu menggunakan fixed effect.

Tabel 2

Uji Hausman-test

\begin{tabular}{cc}
\hline Test Summary & Prob. \\
\hline Cross-section random & 0.0350 \\
\hline
\end{tabular}

Berdasarkan hasil uji hausman test dengan menggunakan Eviews, didapatkan nilai probability sebesar $0,0350<$ (alpha) $5 \%$. Sehingga dapat disimpulkan bahwa model terbaik yang digunakan dalam penelitian ini yaitu menggunakan fixed effect.

Uji Multikolinieritas bertujuan untuk mengetahui apakah model regresi masing masing variabel bebas (independent) saling berhubungan secara linier. ${ }^{14}$ Jika koefisien korelasi antar variabel independent lebih dari 0,8, maka data dalam penelitian mengalami masalah multikolinieritas, sedangkan jika koefisisen korelasi kurang dari 0,8 maka data dalam penelitian terbebas dari masalah multikolinieritas. ${ }^{15}$

\footnotetext{
13 Ibid.

${ }^{14}$ Basuki, Analisis Regresi Dalam Penelitian Ekonomi \& Bisnis: Dilengkapi Aplikasi SPSS \& Eviews.

15 Damodar \& Dawn Porter Gujarati, Dasar-Dasar Ekonometrika Buku, 2nd ed. Jakarta: Salemba Empat, 2013.
} 
Tabel 3

Tabel Nilai Korelasi

\begin{tabular}{cccccc}
\hline & PSR & IIR & ISIR & ZPR & ICG \\
\hline PSR & 1.000000 & -0.043603 & -0.118426 & 0.090049 & -0.064116 \\
IIR & -0.043603 & 1.000000 & -0.096809 & -0.169576 & 0.256140 \\
ISIR & -0.118426 & -0.096809 & 1.000000 & -0.100311 & -0.134794 \\
ZPR & 0.090049 & -0.169576 & -0.100311 & 1.000000 & 0.006349 \\
ICG & -0.064116 & 0.256140 & -0.134794 & 0.006349 & 1.000000 \\
\hline
\end{tabular}

$*$ Fraud sebagai variabel dependen

Berdasarkan tabel di atas dapat dilihat semua koefisien korelasi kurang dari 0,8. Maka disimpulkan tidak terdapat masalah multikolinieritas dalam data penelitian.

Uji autokorelasi bertujuan untuk menguji apakah dalam model regresi linear ada korelasi antara kesalahan pengganggu pada periode $\mathrm{T}$ dengan kesalahan pengganggu pada $\mathrm{T}$ sebelumnya. Untuk mendeteksi masalah Autokorelasi dalam penelitian ini, penulis menggunakan uji Durbin-Watson (DW).

Tabel 5

Hasil Uji Autokorelasi

\begin{tabular}{lllll}
\hline $\mathrm{dL}$ & $\mathrm{dU}$ & $\mathrm{DW}$ & $4-\mathrm{dU}$ & $4-\mathrm{dL}$ \\
\hline 1,60 & 1,25 & 2.133644 & 2,74 & 2,40 \\
\hline
\end{tabular}

Dari hasil Uji Durbin-Witson yang dilakukan didapatkan hasil Durbin-Witson stat sebesar 2,133, nilai ini kemudian dibandingkan dengan nilai tabel dengan menggunakan nilai signifikansi 0,05, jumlah sampel 60 (n) dan jumlah variabel independen $5(\mathrm{k}=5)$ maka didapat nilai $d U$ sebesar 1,25 dan nilai $d L$ sebesar 1,60. Berdasarkan hitungan nilai Dw $>$ du $<4$-du, maka disimpulkan bahwa dalam penelitian ini tidak terdapat masalah autokorelasi.

Tujuan dari Uji heteroskedastisitas untuk mengetahui apakah dalam model regresi terjadi ketidaksamaan varians dari residual satu pengamatan ke pengamatan yang lain. Dalam penelitian akan menggunakan metode dengan uji glejser untuk mendeteksi ada tidaknya heteroskedastisitas dalam model regresi.

Tabel 6

Hasil Uji Heteroskedasitas

\begin{tabular}{cc}
\hline Variabel & Prob. \\
\hline C & 0.3080 \\
PSR & 0.4618 \\
IIR & 0.4131 \\
ISIR & 0.8790 \\
ZPR & 0.6419 \\
ICG & 0.5237 \\
\hline *Residual Obsolut (RESABS) sebagai variabel dependen
\end{tabular}

Hasil uji glejser menunjukkan probabilitas seluruh variabel lebih besar dari 0,05, hal ini berarti bahwa tidak terdapat heteroskedastis dalam model penelitian ini.

Dari hasil uji pemilihan model di atas, maka model yang terbaik digunakan yaitu model estimasi fixed effect. Pada penelitian ini telah dilakukan uji asumsi klasik, dimana dari 
hasil uji tersebut menyimpulkan bahwa model telah lolos dari uji tersebut, dengan demikian hasil estimasi konsisten dan tidak bias. Hasil estimasi model regresi data panel adalah sebagai berikut:

Tabel 7

\begin{tabular}{cc}
\multicolumn{2}{c}{ Hasil Estimasi Regresi } \\
\hline Variabel & Coefficient \\
\hline C & -8.032920 \\
PSR & 0.663345 \\
IIR & -0.272566 \\
ISIR & 0.207374 \\
ZPR & -0.122725 \\
ICG & -0.157548 \\
\hline
\end{tabular}

Dari hasil pengolahan data panel dengan metode fixed effect diperoleh persamaan regresi sebagai berikut:

Fraud $_{\text {it }}=-8.032920+0.663345 P S R$ it $-0.272566 * I^{2} R_{\text {it }}+0.207374 I S I R_{\text {it }}-0.122725 Z P R_{\text {it }}$ $-0.157538 \mathrm{ICG}_{\mathrm{it}}+\mathrm{e}_{\mathrm{it}}$

Keterangan:

Y $\quad$ : Tindakan Fraud (Frekuensi kejadian)

a : Konstanta (Intercept)

X1 : Profit Sharing Ratio (PSR) (\%)

$\mathrm{X} 2 \quad$ : Islamic Investment Ratio (IIR) (\%)

$\mathrm{X} 3 \quad$ : Islamic Income Ratio (IsIR) (\%)

X4 : Zakat Performance Ratio (ZPR) (\%)

X5 : Islamic Corporatee Governance (Skala point)

\section{Uji Hipotesis}

Uji nilai $\mathrm{F}$ bertujuan untuk mengetahui apakah semua variabel independen (PSR, IIR, ISIR, ZPR dan ICG) secara bersama-sama (simultan) berpengaruh terhadap variabel dependen yaitu fraud.

Tabel 8

Hasil Uji F

\begin{tabular}{lll}
\hline Variabel & F-Statistik & Prob (F-Statistik) \\
\hline
\end{tabular}

PSR, IIR, IsIR, ZPR,

dan ICG $\quad 4.417294 \quad 0.000050$

Berdasarkan hasil uji $\mathrm{F}$ pada tabel 8 didapat nilai $\mathrm{F}$ hitung sebesar 4,417294 dengan hasil probabilitas (F-Statistik) sebesar dengan 0.000050. Dapat dilihat pada tabel diatas bahwa nilai probabilitas (F-Statistik) lebih kecil dari 0,05 maka disimpulkan bahwa Profit Sharing Ratio (PSR), Islamic Investment Ratio (IIR), Islamic Income Ratio (IsIR), Zakat Peformace Ratio (ZPR) dan Islamic Corporate Governance (ICG) secara bersama-sama (simultan) berpengaruh terhadap fraud.

\section{Uji Koefisien Determinasi}

Nilai koefisien determinasi ( $R$ square) untuk menunjukkan presentase tingkat kebenaran prediksi dari pengujian regresi yang dilakukan. Koefisien determinasi digunakan untuk memenuhi pengaruh variabel independen terhadap variabel dependen. Nilai $(R$ square) menujukkan seberapa besar model regresi mampu menjelaskan variasi variabel tergantung. 
Tabel 9

Hasil Uji Koefisien Determinasi $\left(\mathrm{R}^{2}\right)$

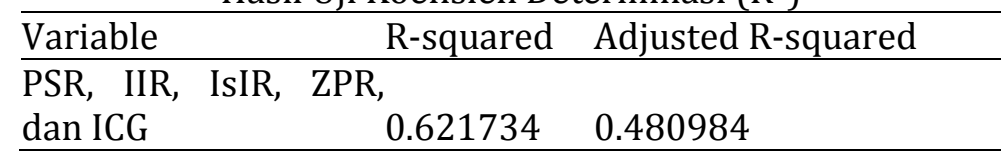

Bedasarkan tabel 9 dapat diketahui bahwa nilai $R$-Squared sebesar 0.621734 ini meunjukkan bahwa variasi variabel PSR, IIR, ISIR, ZPR dan ICG sebesar 62\%. Sedangkan sisanya sebesar $38 \%$ dijelaskan oleh variabel lain diluar varibel yang dipilih.

\section{Uji T (Parsial)}

Uji nilai T bertujuan untuk mengetahui pengaruh secara parsial (individu) variabelvariabel independen (PSR, IIR, ISIR, ZPR dan ICG) terhadap variabel dependen yaitu fraud, dengan melihat nilai probabilitas pada tabel uji statistik T. Apabila nilai probabilitas kurang dari 0.05 berarti variabel independen secara parsial (individu) mempengaruhi variabel dependen.

Tabel 10

Hasil Uji T

\begin{tabular}{lll}
\hline Variable & Coefficient & Prob. \\
\hline C & -8.032920 & 0.7970 \\
PSR & 0.663345 & 0.0000 \\
IIR & -0.272566 & 0.0326 \\
ISIR & 0.207374 & 0.4273 \\
ZPR & -0.122725 & 0.7364 \\
ICG & -0.157548 & 0.9677 \\
\hline
\end{tabular}

Dari tabel 10 bahwa dapat diartikan dari uji statistik sebagai berikut:

\section{Uji Hipotesis 1 (Pengruh Profit Sharing Ratio (PSR) terhadap Fraud)}

Bedasarkan pada tabel 10 tingkat probability $0.0000<\alpha 0.05$ dan nilai koefisien regresi sebesar 0.663345 berarti Profit Sharing Ratio (PSR) berpengaruh positif terhadap Fraud. Sehingga $\mathrm{H}_{1}$ ditolak.

\section{Uji Hipotesis 2 (Pengaruh Islamic Invesment Ratio (IIR) terhadap Fraud)}

Bedasarkan pada tabel 10 diperoleh tingkat probabiliy $0.0326<\alpha 0.05$ dan nilai koefisien regresi sebesar - 0.272566 berarti Islamic Invesment Ratio (IIR) berpengaruh negatif terhadap pembiayaan murabahah. Sehingga $\mathrm{H}_{2}$ diterima.

\section{Uji Hipotesis 3 (Pengaruh Islamic Income Ratio (IsIR) terhadap Fraud)}

Bedasarkan pada tabel 10 diperoleh tingkat probability $0.4273>\alpha 0.05$ dan nilai koefisien regresi sebesar 0.207374. Karena tingkat probability lebih besar dari 0.05 maka secara parsial Islamic Income Ratio (ISIR) tidak berpengaruh secara signifikan terhadap fraud. Sehingga $\mathrm{H}_{3}$ ditolak.

\section{Uji Hipotesis 4 (Pengaruh Zakat Peformance Ratio (ZPR) terhadap Fraud)}

Bedasarkan pada tabel 10 diperoleh tingkat probability $0.7364>\alpha 0.05$ dan nilai koefisien regresi sebesar -0.1227250 . Kerena tingkat probability lebih besar dari 0.05 maka secara parsial Zakat Peformance Ratio (ZPR) tidak berpengaruh secara signifikan terhadap fraud. Sehingga $\mathrm{H}_{4}$ ditolak.

\section{Uji Hipotesis 5 (Pengaruh Islamic Corporate Governance (ICG) terhadap Fraud)}


Bedasarkan pada tabel 10 diperoleh tingkat probability $0.9677>\alpha 0.05$ dan nilai koefisien regresi sebesar -0.157548 . Kerena tingkat probability lebih besar dari 0.05 maka secara parsial Islamic Corporate Governance (ICG) tidak berpengaruh secara signifikan terhadap Fraud. Sehingga $\mathrm{H}_{5}$ ditolak.

\section{HASIL DAN PEMBAHASAN}

\section{Pengaruh Profit Sharing Ratio (PSR) terhadap Tindakan Fraud}

Bedasarkan hasil penelitian, X1 (PSR) menandakan tanda positif dan signifikan secara statistik pada derajat kepercayaan lima persen untuk semua Bank Umum Syariah di Indonesia. Variabel PSR mempunyai koefisien positif yang berarti antara variabel PSR dengan Tindakan Fraud mempunyai hubungan yang positif. Koefisien Profit Sharing Ratio (PSR) mempunyai nilai sebesar 0.663345, yang berarti apabila terjadi kenaikan nilai PSR sebesar $1 \%$ sedangkan variabel lain tetap maka akan menaikan jumlah fraud yang terjadi di Bank Umum Syariah di Indonesia sebesar 0.663345 kejadian fraud.

Terlihat bahwa dalam penelitian ini hubungan antara PSR bernilai positif terhadap Tindakan Fraud, diartikan bahwa ketika variabel yang berada pada sisi kanan model (variabel independen) mengalami kenaikan/penurunan, maka variabel pada ruas kiri akan mengikuti dengan arah yang sama yakni kenaikan/penurunan.

Hal ini mengindikasikan bahwa semakin tinggi PSR pada Bank Syariah maka semakin tinggi pula tindakan fraud yang terjadi di Bank Syariah. Namun terlihat juga bahwa PSR dalam penelitian tidak sesuai dengan hipotesis dalam penelitian ini bahwa variabel PSR berpengaruh negatif terhadap tindakan Fraud pada Bank Umum Syariah di Indonesia.

Muhammad menjelaskan kontrak mudharabah dalam perbankan syariah memiliki resiko yang tinggi. Hal ini disebabkan karena dalam kontrak tersebut mengandung asimetrik informasi. Asimetrik Informasi yaitu kondisi yang memperlihatkan sebagian investor mempunyai informasi sedangkan yang lain tidak memiliki informasi. Asimetrik informasi tersebut bisa berupa moral hazard yang dilakukan oleh agen, selain itu terdapat agency poblem yang ditemui dalam mudharabah antara lain adanya conflict of interest, dimana pengelola (mudharib) bertindak meremehkan hubungan kontraktual dan akan bertindak mengabaikan kepentingan pemilik modal (shahibul maal). ${ }^{16}$

Sehingga dengan mendasar pada hasil analisis yang didukung dengan data kondisi dilapangan, maka dalam menjawab hipotesis pertama dengan bunyi "Diduga variabel PSR berpengaruh secara signifikan dan negatif terhadap tindakan Fraud pada Bank Umum Syariah di Indonesia" tidak dapat dibuktikan dalam penelitian ini.

\section{Pengaruh Islamic Invesment Ratio (IIR) terhadap Tindakan Fraud}

Bedasarkan hasil penelitian, X2 (IIR) menandakan tanda negatif dan signifikan secara statistik pada derajat kepercayaan lima persen untuk semua Bank Umum Syariah di Indonesia. Variabel Islamic Invesment Ratio mempunyai koefisien negatif yang berarti antara variabel IIR dengan tindakan Fraud mempunyai hubungan yang negatif. Koefisien IIR mempunyai nilai sebesar -0.272566 yang berarti apabila terjadi kenaikan IIR sebesar $1 \%$ sedangkan variabel lain tetap maka akan menurunkan jumlah fraud yang terjadi di Bank Umum Syariah di Indonesia sebesar 0.272566 kejadian fraud.

Terlihat bahwa dalam penelitian ini hubungan antara Islamic Invesment Ratio (IIR) bernilai negatif terhadap Tindakan Fraud, diartikan bahwa ketika variabel yang berada pada

16 Muhammad, Manajemen Keuangan Syari'ah Yogyakarta: UPP STIM YKPN, 2016. 
sisi kanan model (variabel independen) mengalami kenaikan/penurunan, maka variabel pada ruas kiri akan mengikuti berlawanan arah yakni penurunan/kenaikan.

Hal ini mengindikasikan bahwa semakin tinggi ratio IIR Bank Syariah maka tindakan Fraud akan mengalami penurunan. Hal ini sesuai dengan hipotesis bahwa variabel IIR berpengaruh negatif terhadap tindakan Fraud pada Bank Umum Syariah di Indonesia.

Berdasarkan teori agensi, apabila nilai investasi yang ditanamkan tinggi, maka manajer telah mengelola dana investor dengan jujur dan baik sesuai dengan tujuan di awal. Apabila manajer sudah bersedia jujur itu berarti dia akan cenderung menghindari melakukan tindakan kecurangan dimana nilai fraud perusahaan akan menurun. Namun hasil penelitian ini tidak sesuai dengan penelitian yang dilakukan oleh Najib dan Rini, yang menyimpulkan Islamic Invesment Ratio (IIR) tidak berpengaruh terhadap fraud.

Sehingga dengan mendasar pada hasil analisis yang didukung dengan data kondisi dilapangan, maka dalam menjawab hipotesis kedua dengan bunyi "Diduga variabel Islamic Invesment Ratio (IIR) berpengaruh secara signifikan dan negatif terhadap tindakan fraud pada Bank Umum Syariah di Indonesia" terbukti memiliki pengaruh yang signifikan terhadap tindakan fraud.

\section{Pengaruh Islamic Income Ratio (IsIR) terhadap Tindakan Fraud}

Berdasarkan hasil penelitian, X3 (Islamic Income Ratio) menandakan tanda positif dan tidak signifikan secara statistik pada derajat kepercayaan lima persen untuk semua Bank Umum Syariah di Indonesia. Variabel Islamic Income Ratio (ISIR) mempunyai koefisien positif yang berarti antara variabel suku bunga Bank Indonesia dengan tindakan fraud mempunyai hubungan yang positif. Koefisien Islamic Income Ratio (IsIR) mempunyai nilai sebesar 0.207374, yang berarti apabila terjadi kenaikan Islamic Income Ratio (IsIR) sebesar 1\% sedangkan variabel lain tetap maka akan menaikan jumlah fraud yang terjadi di Bank Umum Syariah di Indonesia sebesar 0.207374 kejadian fraud.

Terlihat bahwa dalam penelitian ini hubungan antara IsIR bernilai positif terhadap tindakan fraud, diartikan bahwa ketika variabel yang berada pada sisi kanan model (variabel independen) mengalami kenaikan/penurunan, maka variabel pada ruas kiri akan mengikuti dengan arah yang sama yakni kenaikan/penurunan.

Hal ini mengindikasikan bahwa semakin tinggi IsIR pada Bank Syariah maka semakin tinggi pula tindakan fraud yang terjadi di bank syariah. Namun terlihat juga bahwa IsIR dalam penelitian tidak sesuai dengan hipotesis dalam penelitian ini bahwa variabel IsIR berpengaruh negatif terhadap Tindakan Fraud pada Bank Umum Syariah di Indonesia. Dalam penelitian ini Islamic Income Ratio (IsIR) tidak memiliki hubungan yang signifikan terhadap Tindakan Fraud.

Sebagai perbandingan, penelitian yang dilakukan oleh Najib dan Rini, yang menyatakan bahwa Islamic Income Ratio tidak berpengaruh terhadap tindakan fraud pada Bank Umum Syariah dikarenakan kemungkinan masih terdapat kecurangan yang terjadi di dalam bank syariah walaupun rata-rata nilai Islamic Income Ratio yang mendekati $100 \%$ yaitu 0,990070 atau 99\% yang artinya ratio pendapatan yang diperoleh bank syariah telah dilakukan atau didominasi oleh kegiatan yang sesuai prinsip syariah, sehingga pendapatan Islami yang diperoleh bank syariah tersebut tidak berpengaruh terhadap kecurangan yang terjadi.

Sehingga dengan mendasar pada hasil analisis yang didukung dengan data kondisi dilapangan, maka dalam menjawab hipotesis ketiga dengan bunyi "Diduga variabel Islamic Income Ratio (IsIR) berpengaruh secara signifikan dan negatif terhadap Tindakan Fraud pada Bank Umum Syariah di Indonesia" tidak dapat dibuktikan dalam penelitian ini bahwa Islamic Income Ratio (IsIR) memiliki pengaruh yang signifikan terhadap Tindakan Fraud. 


\section{Pengaruh Zakat Peformance Ratio (ZPR) terhadap Tindakan Fraud}

Bedasarkan hasil penelitian, X4 (ZPR) menandakan tanda negatif dan tidak signifikan secara statistik pada derajat kepercayaan lima persen untuk semua Bank Umum Syariah di Indonesia. Variabel Zakat Peformance Ratio (ZPR) mempunyai koefisien negatif yang berarti antara variabel ZPR dengan tindakan fraud mempunyai hubungan yang negatif. Koefisien ZPR mempunyai nilai sebesar - 0.122725, yang berarti apabila terjadi kenaikan ZPR sebesar 1\% sedangkan variabel lain tetap maka akan menurunkan jumlah fraud yang terjadi di Bank Umum Syariah di Indonesia sebesar 0.122725 kejadian fraud.

Terlihat bahwa dalam penelitian ini hubungan antara ZPR negatif terhadap tindakan fraud, diartikan bahwa ketika variabel yang berada pada sisi kanan model (variabel independen) mengalami kenaikan/penurunan, maka variabel pada ruas kiri akan mengikuti berlawanan arah yakni penurunan/kenaikan.

Hal ini mengindikasikan bahwa semakin tinggi ZPR pada Bank Syariah akan menurunkan tindakan fraud yang terjadi di Bank Syariah. Namun terlihat juga bahwa ZPR dalam penelitian tidak sesuai dengan hipotesis dalam penelitian ini bahwa variabel ZPR berpengaruh negatif terhadap tindakan fraud pada Bank Umum Syariah di Indonesia. Dalam penelitian ini Zakat Peformance Ratio (ZPR) tidak berpengaruh terhadap tindakan fraud pada Bank Umum Syariah di Indonesia.

Berdasarkan perhitungan yang dilakukan dalam penelitian ini, rata-rata rasio zakat pada bank syariah berkisar kurang dari $20 \%$, hal ini mengindikasikan zakat yang dikeluarkan Bank Syariah masih relatif kecil. Sebagai perbandingan, penelitian yang dilakukan oleh Asrori, menjelaskan bahwa tujuan utama pendirian Bank Syariah yaitu untuk menciptakan keadilan dan kesejahteraan masyarakat melalui mekanisme zakat. ${ }^{77}$ Dari hasil penelitian yang dilakukan Asrori, menyimpulkan bahwa kinerja Bank Syariah dalam menunaikan zakat masih relatif rendah. Sehingga aktivitas zakat yang dilakukan oleh bank tersebut tidak berpengaruh terhadap kecurangan yang terjadi. ${ }^{18}$

Melihat fenomena ini, maka Bank Syariah perlu meningkatkan aktivitas zakat. Zakat dapat berperan sebagai variabel kontrol dan variabel kebijkasanaan. Sebagai variabel kontrol, zakat dapat digunakkan untuk mencegah pola konsumsi yang berlebihan yang akan berdampak buruk pada masalah ekonomi, seperti inflasi dan ketidakmrataan maupun sebagai alat pendorong untuk timbulnya investasi baru yang akan menciptakan produksi dan kesempatan kerja. Sedangkan sebagai variabel kebijaksanaan, zakat dapat berperan memperbaiki proses distribusi pendapatan yang adil dan merata. Kemungkinan sistem ekonomi dan keuangan tanpa bunga lebih efektif untuk mewujudkan kestabilan ekonomi jangka panjang.

Sehingga dengan mendasar pada hasil analisis yang didukung dengan data kondisi dilapangan, maka dalam menjawab hipotesis keempat dengan bunyi "Diduga variabel Zakat Peformance Ratio (ZPR) berpengaruh secara signifikan dan negatif terhadap tindakan fraud pada Bank Umum Syariah di Indonesia" tidak dapat dibuktikan dalam penelitian ini bahwa Zakat Peformance Ratio (ZPR) memiliki pengaruh yang signifikan terhadap tindakan fraud.

\section{Pengaruh Islamic Corporate Governance (ICG) terhadap Tindakan Fraud}

Berdasarkan hasil penelitian, X5 (Islamic Corporate Governance) menandakan tanda negatif dan tidak signifikan secara statistik pada derajat kepercayaan lima persen untuk

\footnotetext{
17 Asrori, "Implementasi Islamic Corporate Governance Dan Implikasinya Terhadap Kinerja Bank Syariah," JDA Jurnal Dinamika Akuntansi 6, no. No 1 (2014): 90-102.

18 Ibid.
} 
semua Bank Umum Syariah di Indonesia. Variabel Islamic Corporate Governance (ICG) mempunyai koefisien negatif yang berarti antara variabel Islamic Corporate Governance dengan tindakan fraud mempunyai hubungan yang negatif. Koefisien Islamic Corporate Governance (ICG) mempunyai nilai sebesar -0.157548 , yang berarti apabila terjadi kenaikan nilai komposit Islamic Corporate Governance (ICG) sebesar 1 (satu) point sedangkan variabel lain tetap maka akan menurunkan jumlah fraud yang terjadi di Bank Umum Syariah di Indonesia sebesar 0.157548 kejadian fraud.

Terlihat bahwa dalam penelitian ini hubungan antara ICG bernilai negatif terhadap tindakan fraud, diartikan bahwa ketika variabel yang berada pada sisi kanan model (variabel independen) mengalami kenaikan/penurunan, maka variabel pada ruas kiri akan mengikuti dengan arah yang sama yakni kenaikan/penurunan.

Hal ini mengindikasikan bahwa semakin tinggi nilai Islamic Corporate Governance (ICG) pada Bank Syariah maka jumlah tindakan fraud pada Bank Syariah akan menurun. Namun terlihat juga bahwa IsIR dalam penelitian tidak sesuai dengan hipotesis dalam penelitian ini bahwa variabel ICG berpengaruh positif terhadap Tindakan Fraud pada Bank Umum Syariah di Indonesia. Dalam penelitian ini Islamic Corporate Governance (ICG) tidak memiliki hubungan yang signifikan terhadap tindakan Fraud.

Sebagai perbandingan, penelitian yang dilakukan oleh Najib dan Rini, yang menyimpulkan bahwa Islamic Corporate Governance (ICG) tidak berpengaruh terhadap tindakan fraud pada Bank Umum Syariah dikarenakan tata kelola Bank Syariah masih sulit dilaksanakan. Hal ini kemungkinan disebabkan karena Bank Syariah saat ini masih dalam proses pengembangan, sehingga tata kelola perusahaan Bank Syariah belum efektif berpengaruh terhadap kecurangan yang terjadi. Oleh karena itu perlu adanya perbaikan secara berkelanjutan untuk pelaksanaan tata kelola perusahaan agar sesuai dengan prinsipprinsip syariah serta efektif untuk diterapkan.

Selain itu, penelitian ini mendukung penelitian In'airat, dimana dalam penelitian tersebut, In'airat menyimpulkan penerapan corporate governance masih kurang efektif untuk mengurangi tingkat kecurangan (fraud) ${ }^{19}$. Namun, hasil penelitian ini bertentangan dengan penelitian Anugerah, dimana dalam penelitian tersebut, Anugerah menyimpulkan corporate governance dapat mengurangi tingkat kecurangan (fraud). ${ }^{20}$

Sehingga dengan mendasar pada hasil analisis yang didukung dengan data kondisi dilapangan, maka dalam menjawab hipotesis kelima dengan bunyi "Diduga variabel Islamic Corporate Governance (ICG) berpengaruh secara signifikan dan negatif terhadap Tindakan Fraud pada Bank Umum Syariah di Indonesia" tidak dapat dibuktikan dalam penelitian ini bahwa Islamic Corporate Governance (ICG) memiliki pengaruh yang signifikan terhadap Tindakan Fraud.

\section{PENUTUP}

Penelitian ini bertujuan untuk menguji pengaruh Profit Sharing Ratio (PSR), Islamic Invesment Ratio (IIR), Islamic Income Ratio (IsIR), Zakat Peformance Ratio (ZPR), dan Islamic Corporate Governance (ICG) terhadap tindakan fraud pada Bank Umum Syariah (BUS) di Indonesia. Penelitian ini mendapatkan kesimpulan bahwa Profit Sharing Ratio (PSR) berpengaruh positif dan signifikan terhadap tindakan fraud sedangkan Islamic Invesment Ratio (IIR) berpengaruh negatif dan signifikan terhadap tindakan fraud pada Bank Umum

${ }^{19}$ Mohammad In'airat, "The Role of Corporate Governance in Fraud Reduction - A Preception in the Saudi Arabia Business Environment," Journal of Accounting and Finance 15, no. 2 (2015).

20 Rita Anugerah, "Peranan Good Corporate Governance Dalam Pencegahan Fraud," Jurnal Akuntansi 3, no. 1 (2014): 101-13. 
Syariah di Indonesia. Temuan lainnya adalah bahwa Islamic Income Ratio (IsIR), Zakat Peformance Ratio (ZPR), dan Islamic Corporate Governance (ICG) tidak berpengaruh terhadap tindakan fraud pada Bank Umum Syariah di Indonesia. Hal ini menunjukkan bahwa Profit Sharing Ratio (PSR) dapat menjadi salah satu indikator untuk menentukan kemungkinan adanya potensi fraud di Bank Umum Syariah di Indonesia.

Implikasi yang dapat dirumuskan dari penelitian ini antara lain: pertama, indikatorindikator keuangan dan non keuangan sebenarnya dapat digunakan sebagai alat kendali untuk menentukan tingkat potensi fraud yang ada di lembaga keuangan syariah. Kedua, regulator dapat mengembangkan indikator-indikator keuangan dan non keuangan untuk membantu mengantisipasi adanya potensi fraud karena fraud menjadi salah satu aspek yang dapat menurunkan tingkat profitabilitas serta meningkatkan biaya litigasi dalam rangka menyelesaikan kasus fraud yang terjadi. Sikap kehati-hatian (prudential banking) dalam menjalankan kegiatan operasionalnya perlu dimiliki oleh jajaran manajerial di perbankan syariah termasuk juga fungsi pengawasan internal yang secara langsung dijalankan oleh dewan komisaris dan dewan pengawas syariah.

\section{DAFTAR PUSTAKA}

Anugerah, Rita. "Peranan Good Corporate Governance Dalam Pencegahan Fraud." Jurnal Akuntansi 3, no. 1 (2014): 101-13.

Asrori. "Implementasi Islamic Corporate Governance Dan Implikasinya Terhadap Kinerja Bank Syariah." JDA Jurnal Dinamika Akuntansi 6, no. No 1 (2014): 90-102.

- - - "Pengungkapan Syari'Ah Compliance Dan Kepatuhan Bank Syariah Terhadap Prinsip Syariah." JDA Jurnal Dinamika Akuntansi 3, no. 1 (2011): 1-7.

Basuki, Agus Tri. Analisis Regresi Dalam Penelitian Ekonomi \& Bisnis: Dilengkapi Aplikasi SPSS \& Eviews. Jakarta: Rajawali Pers, 2016.

Caphra, M.U. \& Ahmed, Habib. "Corporate Governance In Islamic Financial Institutions." Occasional Paper No. 6 Jeddah 13, no. 4 (2002): 375-89.

Falikhatun, and Yasmin Umar Assegaf. "Bank Syariah Di Indonesia : Ketaatan Pada PrinsipPrinsip Syariah Dan Kesehatan Finansial." Conferene in Business, Accounting and Management-FE UNISSULA 1 No. 1, no. Desember (2012): 245-54.

Gujarati, Damodar \& Dawn Porter. Dasar-Dasar Ekonometrika Buku. 2nd ed. Jakarta: Salemba Empat, 2013.

Hameed, Shahul, Ade Wirman, Bakhtiar Alrazi, Mohd N M. Nor, and Sigit. Pramono. "Alternative Disclosure and Performance Measures for Islamic Banks," 2004. https://doi.org/10.1017/CB09781107415324.004.

In'airat, Mohammad. "The Role of Corporate Governance in Fraud Reduction - A Preception in the Saudi Arabia Business Environment." Journal of Accounting and Finance 15, no. 2 (2015).

Maradita, Aldira. “Karakteristik Good Corporate Governance." Yuridika 29, no. 2 (2014): 191204.

Muhammad. Manajemen Keuangan Syari'ah. Yogyakarta: UPP STIM YKPN, 2016.

Najib, Haifa, and Rini. "Sharia Compliance, Islamic Corporate Governance, Dan Fraud Pada Bank Syariah." Akuntansi Dan Keuangan Islam 4.2, no. i (2016): 131-46.

Rini. "The Effect of Audit Committee Role and Sharia Supervisory Board Role on Financial Reporting Quality at Islamic Banks in Indonesia." Journal of Economics, Business, and Accountancy/ Ventura 17, no. 1 (2014): 145-56.

"Setitik Nila Di Perbankan Syariah." 2013. http://stabilitas.co.id/home/detail/setitik-nila-di-perbankan-syariah. 
Rifqi Muhammad, Ratna Kusumadewi, Samsubar Saleh

Widarjono, Agus. Ekonometrika Pengantar Dan Aplikasinya. Yogyakarta: Ekonisia FE UII, 2009. 